\title{
THE EFFECTS OF THE TOEFL PREPARATION PROGRAM ON READING SKILLS AND STRUCTURE MASTERY OF PROSPECTIVE STUDENTS
}

\author{
Yohanes Heri Pranoto \\ Musi Charitas Catholic University, Palembang \\ heri_pranoto@ukmc.ac.id
}

\begin{abstract}
Preparation is one step for someone to be mentally feasible and skillful to join and be a part of an activity or a group. Likewise is for senior high school students proposing to go to higher education. One challenge for those prospective university students is the mastery of English - a scientific language. The study aims at finding out the effects of the TOEFL preparation program on the reading skills and structure mastery. Moreover, gentle perceptions are gained to ascertain the course design implementation. Up beyond than those aims, this English reading and structure course is held to assisting the prospective students, at the level of pre-intermediate English skills, ready to continue to higher education level. All students from the final level were assigned as the sample of the study. one-group experiment design, with pre-posttest design, is used to perceive the effectiveness of the course. The findings show the positive effects occur only on the reading skills. However, the test-result discussion on the structure is held to observe the wash-back effects on the test performance.
\end{abstract}

Keywords: reading skills, structure, preparation course

\section{INTRODUCTION}

High school and higher education - college - play a very important role in building the human, both always have differences. Seyabi (2017) said that "Schools have the premise of helping students gain the skills and competencies that would be handful for whatever college or career path they get to choose" ( $p$. 125). Meanwhile, colleges are on preparing them become professional and socially responsible citizens who are capable of being engaged in both contemporary and future concerns of their societies.

Those differences bring the different academic perspective which leads into diversity on something cultural. Downing (2014) gave some views on the differences that they are complex and sometimes need approval. One difference is that high school culture usually assumes immaturity, while college culture expects maturity. When the school students have few choices and less freedom, college students have many choices and much more freedom.

There are some requisites of for students to be ready going on to the college level. They must have spiritual attitudes, interests, ideals, confidence, freedom of spirit, and must be disciplined in carrying out all their duties and obligations as a student (Liu, 2014). The other requisite is that they live in a good home and college environment, and must have good physical and mental health (Hill \& Liu, 2012). 
Another requisite tends to be more academic which is on the knowledge and performance on the international language. The English mastery - one of the 9 international languages - gives some benefits for the students, which are for TOEFL as the academic admission, scholarships, and lectures (English classes, literacy, conversations, etc.). In some cases, this belief increasingly enforces the students to take extra classes of English (Sudrajat \& Astuti, 2018).

One instrument for assessing English language skills is TOEFL. TOEFL has been believed to be one of the most credible English proficiency tests in the world since its establishment in 1963. This test issued by the National Council of the Testing English as a Foreign Language is used by more than 8,000 institutions worldwide and by millions of people in the world.

TOEFL, which is to evaluate English language skills for those whose first language is not English, has got several changes and development in forms, formats, and purposes. Since 1963, there have been three times of changes in format, namely Paper-Based Test, Computer-Based Test, and internet-Based Test. Paper based TOEFL has three main parts of the test, listening comprehension (50 question items - 35 minutes), structure and written expression (40 question items - 25 minutes), and reading comprehension (50 question items - 50 minutes). These parts would be different in the other test formats.

When TOEFL becomes very well-known due to its validity and reliability, there has been the development on the existence - even urgency - of TOEFL preparation program. The preparation program involves 3 main categories (Liu, 2014):

1) Test- taking orientation $\rightarrow$ to help participants to get used to the procedure for carrying out tests,

2) Coaching $\rightarrow$ to intensively assist participants get used to test questions, and

3) Training in broadly applicable cognitive skills $\rightarrow$ to improve the cognitive skills of participants.

The success of the well-organized preparation program and the continuance process of transforming the knowledge to the actual performance of a language are gently affected by the perception. Powers (2012) argues that desires and positively well perceived values play significant role on the effectiveness of the program to achieve its significance. In this study, the perceptions are gained after the program delivery to perceive the students' comments towards the course and material design.

Seminary as a formal school of formation for prospective Catholic priests has its challenge on attempting the seminarian (students of Seminary) master English. This has become the focus of the school for years. Minor Seminary, a school level equal to senior high school, works on preparing the young generation of catholic priest to be capable not only on the personal and religious values but also on academic and professional competence.

The seminarian takes four years of education. Each class has its name, Gramatica (tenth grade), Syntaxis (eleventh grade), Poecis (twelfth grade), and Rhetorica (one year after senior high school). The vision of this seminary is developing pro-rata in $4 \mathrm{Ss}$ - Sanctitas (holiness), Sanitas (health), Scientia (knowledge and scientific), and Socialitas (sociality and togetherness) (Seminari Menengah St. Paulus, 2014). 
Rhetorica is the final level of the education. The seminarian gets different curriculum. The curriculum is set to prepare them entering the higher level of seminary which is equivalent to the college level where they will study philosophy and theology. Thus all activities under the curriculum are set, one of all, for the students to be ready on facing the fundamental difference between senior high and higher education.

Unfortunately, having lack continuous program on English mastery becomes the other problem of the school. The program should aid the students be familiar with the TOEFL questions and administration in doing the test. Moreover, they should also have a good mastery in English for the better achievement and performance in the higher level of education.

\section{Research Problems}

By this research, there were three questions to answer:

1. Was there a significant difference in the TOEFL structure mastery between before and after the students experienced the program?

2. Was there a significant difference in the TEOFL reading comprehension between before and after the students experienced the program?

3. What was the students' perception towards the implementation of the program?

\section{Research Objectives}

This research is mainly to find out the answers against the formulated problems. Therefore, this research is to find out:

1. whether or not there was a significant difference in the TOEFL structure mastery between before and after the students experienced the program;

2. whether or not there was a significant difference in the TEOFL reading comprehension between before and after the students experienced the program;

3. the students' perception towards the implementation of the program.

\section{METHOD}

\section{Research Design}

a) Experimental research within-group design with pre- and post-test

Experimental Research is implemented when cause and effect between independent and dependent variables are tried to find out (Creswell, 2012). This study was considered as within-group design since the researcher uses one group. This is due to the condition when "The participants may be limited and it may not be possible to involve more than one group" (Creswell, 2012, p. 301). Meanwhile, pre- and post-test are functioned to deduce if there was a significant difference between before and after the intervention.

b) Basic scheme

The basic schema of the study is explained as follows:

$$
\mathrm{E}=\mathrm{O} 1 \mathrm{X} \mathbf{O 2}
$$

Where:

$\mathrm{E}=$ Experiment Group

O1 = Pre-test for Experimental Group 
$\mathrm{O} 2=$ Post-test for Experimental Group

$\mathrm{X}=$ Treatment for Experimental Group

\section{Population and Sample}

The population of the research is the Rethorica students of the seminary. In order to select the sample, the purposive sampling technique will be implemented. It considers previous knowledge of a population and the specific purpose of the study.

The sample of the study was the Rethorica students selected purposely due to the difference on the English competences. They were, by the ready-made pretest instruments by Language Centre of a university, placed on the preintermediate level of English competence, where the TOEFL (predicted) score was below 350 .

\section{TOEFL Structure and Reading Preparation Program}

The following is the procedure (in the time table format) of the program:

Table 1: TOEFL Structure and Reading Preparation Program

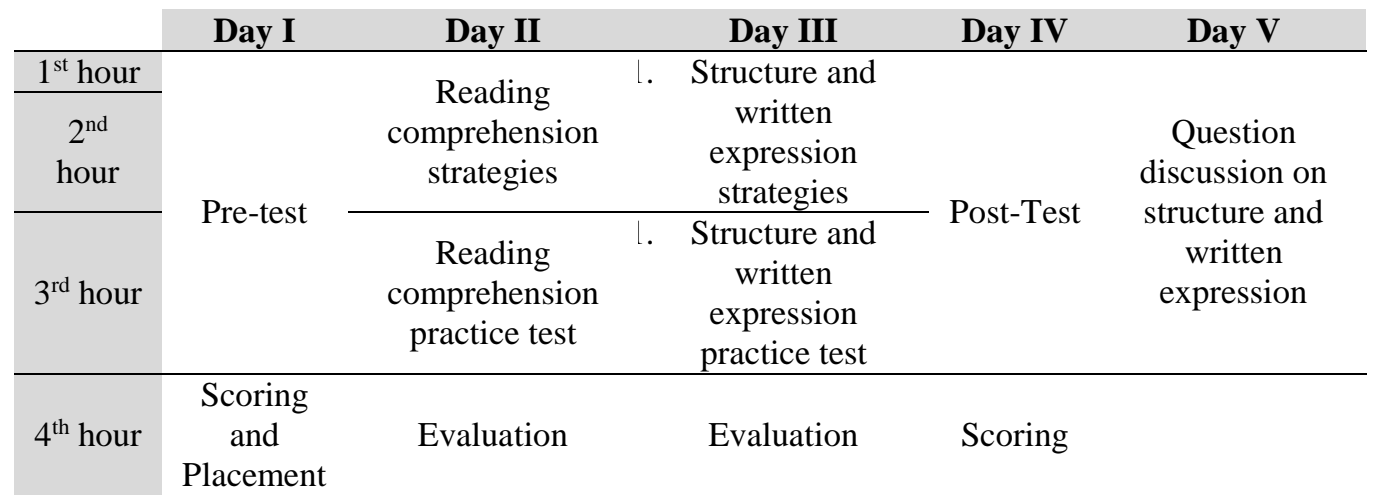

\section{Technique of Collecting Data}

There were two instruments to collect the data - writing test rubric. The first is test. The test used was adopted from the English Proficiency Test developed by Language Centre of Musi Charitas Catholic University. The number of the items for Structure and Written Expression and Reading Comprehension were just the same as what are in TOEFL standard.

Questionnaire was the second instrument. The questionnaire items were adapted from the template issued by research and community services canter, so they were fitted in order to collecting information on the students' perception about the implementation of the program. The questionnaire was divided into two, open-ended questions and closed-ended questions; there are 6 questions for closed-ended questions and two questions for open-ended questions.

The following are the content items for the program:

Table 2: Content Items for the Program

\begin{tabular}{ccccc} 
& Skill I & Skill II & Skill III & Skill IV \\
\hline Structure and & Subject and & Objects of & Appositives & Compound and \\
Written & Verb & Preparation & & complex \\
Expression & & & & sentences
\end{tabular}




\section{Technique of Analyzing Data}

The data were analyzed by the use of a dependent t-Test. The t-Test was used to compare the results of the structure and written expression and reading comprehension between pre-test and post-test. Those kinds of t-Test were analyzed by using SPSS 22. Meanwhile the questionnaire adapted from the research and community services center results were analyzed by the percentage of the respondents' responses.

\section{RESULTS}

The findings cover: (1) the results of the TOEFL structure and written expression test, (2) the results of the TOEFL reading comprehension test, (3) the results of the total TOEFL score, (4) the statistical analysis results, and (5) the students' responses towards the implementation of the program.

\section{The results of the TOEFL structure and written expression test}

The following is a recapitulation of structure and written expression score for pre- and post-tests. The score was scripted based on the correct numbers of the question in this part.

Table 3: The Results of the TOEFL structure and written expression test

\begin{tabular}{|c|c|c|}
\hline St. & Structure (Pre) & Structure (Post) \\
\hline 1 & 38 & 41 \\
\hline 2 & 40 & 37 \\
\hline 3 & 40 & 41 \\
\hline 4 & 36 & 36 \\
\hline 5 & 33 & 42 \\
\hline 6 & 40 & 41 \\
\hline 7 & 36 & 35 \\
\hline 8 & 43 & 38 \\
\hline 9 & 37 & 38 \\
\hline 10 & 38 & 36 \\
\hline 11 & 37 & 37 \\
\hline 12 & 31 & 37 \\
\hline 13 & 23 & 40 \\
\hline 14 & 27 & 37 \\
\hline
\end{tabular}

\section{The results of the TOEFL reading comprehension test}


The following is a recapitulation of reading comprehension score for preand post-tests. The score was scripted based on the correct numbers of the question in this part.

Table 4: The Results of the TOEFL reading comprehension test

\begin{tabular}{|c|c|c|}
\hline St. & Reading (Pre) & Reading (Post) \\
\hline 1 & 41 & 47 \\
\hline 2 & 40 & 45 \\
\hline 3 & 35 & 37 \\
\hline 4 & 44 & 42 \\
\hline 5 & 44 & 44 \\
\hline 6 & 41 & 43 \\
\hline 7 & 41 & 37 \\
\hline 8 & 38 & 43 \\
\hline 9 & 40 & 36 \\
\hline 10 & 32 & 39 \\
\hline 11 & 40 & 44 \\
\hline 12 & 35 & 41 \\
\hline 13 & 39 & 39 \\
\hline 14 & 32 & 37 \\
\hline
\end{tabular}

\section{The results of the total TOEFL scores}

The following is a recapitulation of the TOEFL score for pre- and post-tests. The test was adopted from the English Proficiency Test questions developed by the Language Centre.

Table 5: The Results of the total TOEFL score

\begin{tabular}{ccc} 
St. & TOEFL (Pre) & TOEFL (Post) \\
\hline 1 & 413 & 436 \\
\hline 2 & 406 & 430 \\
\hline 3 & 406 & 426 \\
\hline 4 & 403 & 400 \\
\hline 5 & 396 & 443
\end{tabular}




\begin{tabular}{ccc} 
St. & TOEFL (Pre) & TOEFL (Post) \\
\hline 6 & 393 & 430 \\
\hline 7 & 393 & 383 \\
\hline 8 & 393 & 393 \\
\hline 9 & 380 & 383 \\
\hline 10 & 373 & 400 \\
\hline 11 & 373 & 416 \\
\hline 12 & 336 & 383 \\
\hline 13 & 330 & 393 \\
\hline 14 & 303 & 373
\end{tabular}

\section{The statistical analysis results}

The following is the statistical analysis of the test results. SPSS 22 was used to get the results.

Table 6: Paired Sample t-Test Results

\begin{tabular}{|c|c|c|c|c|c|c|c|c|c|}
\hline & \multicolumn{5}{|c|}{ Paired Differences } & \multirow{3}{*}{$\mathrm{t}$} & \multirow{3}{*}{ df } & \multirow{3}{*}{$\begin{array}{l}\text { Sig. (2- } \\
\text { tailed) }\end{array}$} \\
\hline & & \multirow[t]{2}{*}{ Mean } & \multirow[t]{2}{*}{$\begin{array}{l}\text { Std. } \\
\text { Devia } \\
\text { tion }\end{array}$} & \multirow[t]{2}{*}{$\begin{array}{l}\text { Std. } \\
\text { Error } \\
\text { Mean }\end{array}$} & \multicolumn{2}{|c|}{$\begin{array}{l}95 \% \\
\text { Confidence } \\
\text { Interval of } \\
\text { the } \\
\text { Difference }\end{array}$} & & & \\
\hline & & & & & $\begin{array}{l}\text { Lowe } \\
\mathrm{r}\end{array}$ & Upper & & & \\
\hline $\begin{array}{l}\text { Pair } \\
1\end{array}$ & $\begin{array}{l}\text { Lcpre } \\
\text { convrtd } \\
- \\
\text { Lcpost } \\
\text { convrtd }\end{array}$ & 3.429 & 3.005 & .803 & -5.164 & -1.693 & -4.268 & 13 & .001 \\
\hline $\begin{array}{l}\text { Pair } \\
2\end{array}$ & $\begin{array}{l}\text { Swpre } \\
\text { convrtd } \\
- \\
\text { Swpost } \\
\text { Convrtd }\end{array}$ & 2.643 & 5.943 & 1.588 & -6.074 & .789 & -1.664 & 13 & .120 \\
\hline Pair & Rcpre & 2.286 & 3.750 & 1.002 & -4.451 & -.120 & -2.280 & 13 & .040 \\
\hline
\end{tabular}

The paired sample t-Test showed that the Sig value. (2-tailed) was 0.120> 0.05 . Because Sig. (2-tailed) of 0.120 was greater than 0.05 , it could be concluded that there was no significant effect on TOEFL Structure learning. Moreover, the Sig value (2-tailed) was $0.040<0.05$. Because Sig. (2-tailed) of 0.040 was smaller than 0.05 , it can be concluded that there was a significant effect on TOEFL Reading Comprehension learning.

Sig value. (2-tailed) was $0.001<0.05$. Because Sig. (2-tailed) of 0.001 was smaller than 0.05 , it could be concluded that there was a significant effect on the overall learning skills (Structure and Reading Comprehension). 


\section{The students' responses towards the implementation of the program}

The students' responses towards the implementation of the program were gathered by the questionnaire. There were two kinds of the questions, which were closed questions and open questions. The following is the results of those kinds of the questions for both skills as the target.

\section{a. Structure and written expression}

1) Closed-ended questions

The following is the closed ended questions results on structure and written expression.

Table 7: Structure and written expression: Closed ended-question results

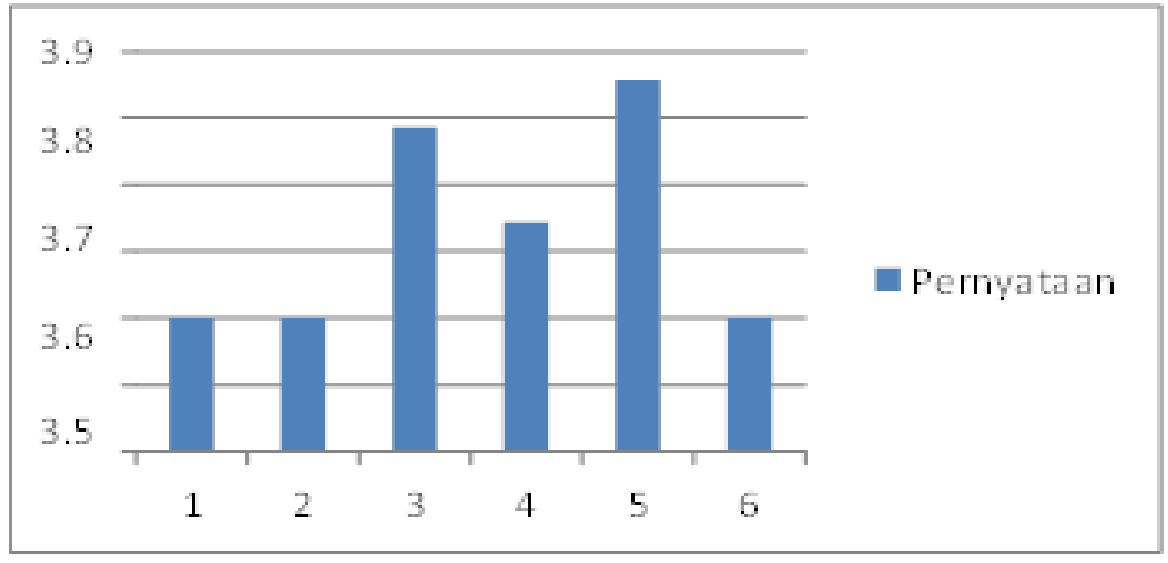

Based on the accumulation of those 6 statements, the average of 3.63 was obtained. This showed that students more than agreed on each statement for the TOEFL Structure and written expression.

\section{2) Open-ended questions}

The following is the results of the open-ended questions.

Table 8: Structure and written expression: Open-ended question results

\begin{tabular}{cl} 
St. & \multicolumn{1}{c}{ Responses } \\
\hline $\mathbf{1}$ & $\begin{array}{l}\text { Learning this time was very exciting and this was the first time I could } \\
\text { understand the structure of English. }\end{array}$ \\
\hline $\mathbf{2}$ & $\begin{array}{l}\text { This activity was very interesting. Other topics were highly expected at the next } \\
\text { meeting. }\end{array}$ \\
\hline $\mathbf{3}$ & $\begin{array}{l}\text { Learning material is interesting and the explanation given is easily understood } \\
\text { by the audience. }\end{array}$ \\
$\mathbf{4}$ & $\begin{array}{l}\text { In my opinion this kind of activity could be continued since it gave much insight } \\
\text { into English. The learning delivery was quite good and interesting. }\end{array}$ \\
\hline
\end{tabular}

5 The topic was interesting and understandable. Activities were also not boring. 


\begin{tabular}{cl} 
St. & \multicolumn{1}{c}{ Responses } \\
\hline $\mathbf{6}$ & I really hoped that we would continue this activity in the next level of learning. \\
\hline $\mathbf{7}$ & The overall topic, material, and delivery were interesting and good. \\
\hline $\mathbf{8}$ & $\begin{array}{l}\text { This topic could be developed and the activities of learning were very } \\
\text { interesting. }\end{array}$ \\
\hline $\mathbf{9}$ & This was an interesting activity. \\
\hline $\mathbf{1 0}$ & $\begin{array}{l}\text { In my opinion, the activities with this topic were important to do and this topic } \\
\text { was important to continue. }\end{array}$ \\
\hline $\mathbf{1 1}$ & $\begin{array}{l}\text { This program was very interesting and easy to understand. There might be many } \\
\text { topics that I hoped for in the next program. }\end{array}$ \\
\hline $\mathbf{1 2}$ & $\begin{array}{l}\text { All that was taught was very meaningful to me because it could increase } \\
\text { knowledge about the TOEFL. Hopefully this activity would become an annual } \\
\text { event for this seminary. }\end{array}$ \\
\hline $\mathbf{1 3}$ & Learning materials were quite interesting, but it took long time. \\
\hline $\mathbf{1 4}$ & $\begin{array}{l}\text { This activity was very helpful to understand English, and other topics were } \\
\text { highly expected. }\end{array}$
\end{tabular}

\section{b. Reading Comprehension}

1) Closed-ended questions

The following is the closed ended questions results on the reading comprehension.

Table 9: Reading Comprehension: Closed ended-question results

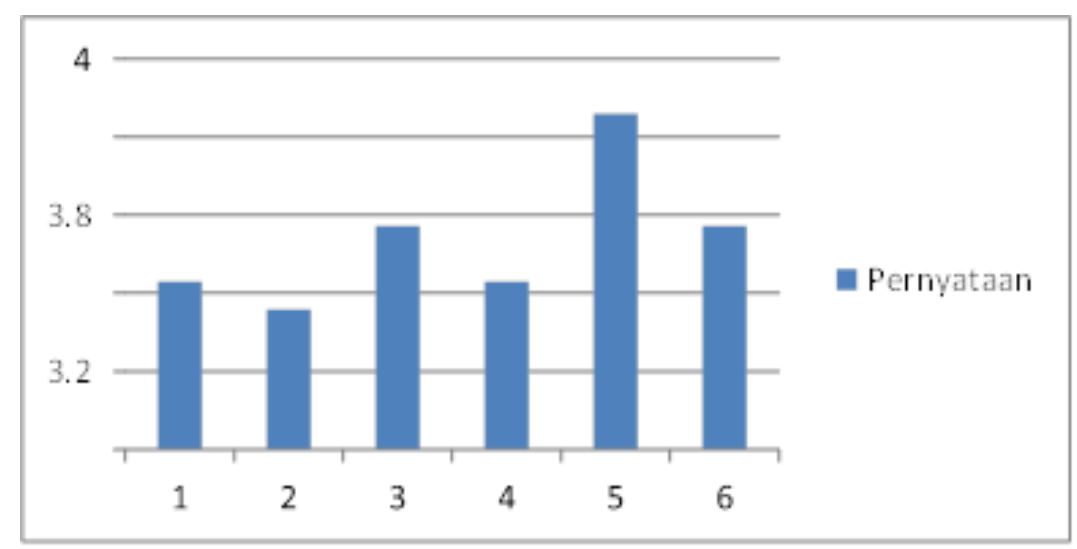

Based on the accumulation of those 6 statements, the average of 3.54 was obtained. This showed that students more than agreed on each statement for the TOEFL Structure and written expression.

\section{2) Open-ended questions}

The following is the results of the open-ended questions on the reading comprehension

\begin{tabular}{cl} 
St. & \multicolumn{1}{c}{ Responses } \\
\hline $\mathbf{1}$ & $\begin{array}{l}\text { This program made me want to learn more about this lesson because it is } \\
\text { very challenging. }\end{array}$ \\
\hline $\mathbf{2}$ & $\begin{array}{l}\text { the activities that had just been carried out were very helpful. The activity } \\
\text { was very interesting and could train though to solve problems with the } \\
\text { methods taught. }\end{array}$
\end{tabular}


3 The explanation (delivery) was fast enough that sometimes it was difficult to understand what was being taught

\begin{tabular}{|c|c|}
\hline 4 & $\begin{array}{l}\text { The method of delivery and explanation of the material was very clear, but } \\
\text { the time used was too fast, so unfortunately we lacked time. }\end{array}$ \\
\hline 5 & $\begin{array}{l}\text { Topics, material, and delivery were very interesting and good. My suggestion } \\
\text { was that this activity would still be held on other topics. }\end{array}$ \\
\hline 6 & the material was delivered interestingly and understandably. \\
\hline 7 & $\begin{array}{l}\text { In my opinion, a similar topic could be continued because it really helped to } \\
\text { improve English reading skills. Besides, the activity was quite interesting. }\end{array}$ \\
\hline 8 & $\begin{array}{l}\text { The activities carried out were very useful because they could bring the } \\
\text { audience to learn quickly what had been delivered. The form of activity kept } \\
\text { the audience focused. If there was an interesting topic, it could be shared } \\
\text { again because it invited the audience to focus. }\end{array}$ \\
\hline 9 & $\begin{array}{l}\text { In my opinion, this explanation was very fast. This resulted in the } \\
\text { participants including me being confused and unclear. It would be better to } \\
\text { explain the material not too fast so that it was easy to understand. }\end{array}$ \\
\hline 10 & $\begin{array}{l}\text { In my opinion, this activity or similar activity could be done again. More } \\
\text { interesting and doable activities were to use the question and answer method } \\
\text { and a little animation. }\end{array}$ \\
\hline 11 & $\begin{array}{l}\text { I really hoped this activity could be done again. My advice was the activity } \\
\text { could use interesting questions. }\end{array}$ \\
\hline 12 & $\begin{array}{l}\text { If there was still the other time, it could be held again so that the similar } \\
\text { interesting activities can increase knowledge. If it was still possible, a new } \\
\text { topic was required. }\end{array}$ \\
\hline 13 & In my opinion, topics like this could be held again. \\
\hline 14 & $\begin{array}{l}\text { This program made me want to learn more about this lesson because it is } \\
\text { very challenging. }\end{array}$ \\
\hline
\end{tabular}

Table 10: Reading Comprehension: Open-ended question results

\section{DISCUSSION}

Based on the results, the negative effect showed up on the structure and written expression competences. The lack of the grammar knowledge might become the gist of the students' difficulties in understanding the use of specific grammar in very limited context description in the questions. The positive result, however, appeared where vocabulary and grammar were put together in a certain descriptive context in passages. The students responded positively and the results of the reading post-tests were significantly accepted improved. According to Powers (2012), characteristics of the complex directions administered under timed condition can simply refract the students' knowledge to the mistaken application, and since then, extending lesson learned is necessary. Powers likewise found that besides unfamiliarity with the test administrations, the readiness of the students toward the preparation set in a program setting might also influence the achievements by the end of the course. By the questionnaire results, however, it was reflected that the students' responses toward the implementation of the program were positive. These results are in line with the research reported by Sudrajat and Astuti (2018) in which the positive perceptions towards the preparation program are prominent to further and beyond learning.

\section{CONCLUSIONS}


Referring to the research questions, there are three conclusions derived from the results and discussion.

1. The structure and written expression of the students did not significantly improve. However, the feedbacks were good. As a result, the further training on structure and written expression was continued by discussing the structure questions as the wash-back.

2. The reading comprehension of the students significantly improved, and it was proved by the statistical data and the students' responses.

3. From the questionnaire, it was summarized that the students' perception toward the implementation of the program was very good. The students gave the suggestions for the same program with different skill focuses. school:

The following are some suggestions. Both suggestions were addressed to the

1. English language training needed to be focused on learning strategies and TOEFL training.

2. Based on the results of the closed- and open-ended questionnaire, it was found that the TOEFL Structure and Written Expression and Reading Comprehension could make good contributions by knowing the right learning strategies.

\section{ACKNOWLEDGMENT}

We gratefully thank to the Rector of St. Paul Minor Seminary Palembang for his kind hearted allowing me do the research. Our gratitude also goes to the head of $L P P M$ for the fund support, so the research could run efficiently.

\section{REFERENCES}

Brown, H. D. (2004). Language assessment: Principles and classroom practices. White Plains, NY: Pearson Education.

Creswell, J. W. (2005). Educational research: planning, conducting, and evaluating quantitative and qualitative research $\left(2^{\text {nd }}\right.$ Ed.). Upper Saddle River, NJ: Pearson Education, Inc.

Creswell, J. W. (2012), Educational research: planning, conducting, and evaluating quantitative and qualitative research ( ${ }^{\text {th }}$ Ed.). Boston, M.A.: Pearson Education, Inc.

Downing, S. (2014). On course: Strategies for creating success in college and in life $\left(7^{\text {th }}\right.$ Ed.). Boston, MA: Wadsworth.

Education Testing Service (ETS). (2001). TOEFL Test and core manual. Princeton, NJ: Educational Testing Service.

Hill, Y. Z., \& Liu, O. L. (2012). Is there any interaction between background knowledge and language proficiency that affects TOEFL iBT reading performance. Retrieved from TOEFL iBT Research Report website: http://144.81.87.152/Media/Research/pdf/RR- 12-22.pdf

Liu, O. L. (2014). Investigating the relationship between test preparation and TOEFL iBT performance (Research Report No. RR-14-15). Princeton, NJ: Educational Testing Service. Doi: 10.1002/ets2.12016 
Powers, D. E. (2012). Understanding the impact of special preparation for admissions tests. Princeton, New Jersey: ETS.

Seminari Menengah St. Paulus (2014). Buku pedoman formatio. Palembang: Seminari Menengah St. Paulus.

Seyabi, F. A. (2017). Students' and teachers' views on school-university partnership in the Omani EFL context. International Education Studies 10(3). 125-133.

Sudrajat, W. N. A., \& Astuti, E. R. (2018). Students' perception of the use of TOEFL preparation online course on the test performance: The case of TOEFL structure and written expression test. Humaniora, 9(3), 275-282. Doi: 10.21512/humaniora.v9i3.4807

U.S. Department of Education. (November, 2016). Advancing diversity and inclusion in higher education. Washington, DC: Office of Planning, Evaluation, and Policy Dev 